\title{
Hoạt động lựa chọn nhà đầu tư thực hiện dụ̣ án: Quy định pháp lý và thực tiễn
}

\section{Selection of investors for real estate project: Legal framework and practical aspects}

\author{
Phan Ngọc Thùy Như ${ }^{1 *}$ \\ ${ }^{1}$ Trường Đại học Mở Thành phố Hồ Chí Minh, Việt Nam \\ *Tác giả liên hệ, Email: nhu.pnt@ou.edu.vn
}

THÔNG TIN

DOI: $10.46223 / \mathrm{HCMCOUJS.}$ proc.vi.16.1.1863.2021

Ngày nhận: 7/3/2021

Ngày nhận lại: 31/3/2021

Duyệt đăng: 9/4/2021

Tì khóa:

thị trường bất động sản, lựa chọn chủ đầu tư, đấu thầu dự án, đấu giá quyền sử dụng đất
TÓM TẮT

Thị trường bất động sản được xem là một trong ba thị truờng nguồn lực đầu vào chủ đạo của nền kinh tế Việt Nam bên cạnh thị trường lao động và thị trường vốn, là một trong những bộ phận không thể tách rời của hệ thống kinh tế thị trường. Trong thời gian qua, mặc dù khung pháp lý liên quan đến thị trường bất động sản ngày càng hoàn thiện, khắc phục các bất cập của cơ chế chính sách, điều chỉnh nhiều vấn đề phát sinh từ thực tiễn, tuy nhiên trong quá trình vận hành, một số văn bản pháp lý vẫn chưa được bổ sung, sửa đổi kịp thời nhằm tháo gỡ những khó khăn của các chủ thể tham gia thị trường, đặc biệt là khung pháp lý có liên quan đến hoạt động lựa chọn nhà đầu tư thực hiện dự án bất động sản. Bài viết tiến hành phân tích quy trình thực hiện lựa chọn chủ đầu tư thực hiện dự án, phát hiện những vướng mắc và tồn tại trong quá trình thực thi các quy định pháp lý có liên quan, từ đó đưa ra một số gợi ý nhằm tháo gỡ các khó khăn, đảm bảo tính pháp lý của các dự án, hướng đến một thị trường bất động sản hiệu quả và minh bạch hơn, hướng đến hoàn thiện các quy định pháp lý về hoạt động lựa chọn chủ đầu tư thực hiện dự án, bảo đảm tính hợp pháp, tính đồng bộ và khả thi của các văn bản quy phạm pháp luật liên quan đến hoạt động này.

\section{ABSTRACT}

The real estate market is one of the integral parts of the economic system, it is considered one of the three resource input markets of the Vietnamese economy with the labor market and the capital market. Developing a real estate market is a major goal for Vietnam's economic development. In recent years, although the legal framework related to the real estate market has been increasingly improved, overcoming the problems of policy updates. With the Land Law, Housing Law, Bidding Law and Law on Real Estate Business, the nation has a basic legal framework in place for real estate market, although limitations exist in current regulations, especially the legal framework related to investors selection for real estate project implementation. The purpose of this paper is to explore the 
Keywords:

real estate market, projects bidding, real estate law, selection of real estate developers

process from legal perspective of how residential real estate is developed and the selection of real estate developers. In addition, the research was conducted to find out problems and shortcomings in current legal framework relating to investors selection for real estate project and provide suggestions in hope of eliminating difficulties in bidding - required projects, aim to the real estate market efficiency with the more reasonable legal framework.

\section{Giới thiệu}

“Quản lý chặt chẽ đất đai và thị trường bất động sản, thưc hiện đúng Luật Đất đai và hoàn chinh hệ thống pháp luật về đất đai" đã là chủ trương của Đảng ta từ giai đoạn đầu của đổi mới kinh tế, đã đuợc quy định rõ trong Báo cáo chính trị tại Đại hội Đảng khoá VIII (1996) về quyết định chủ trương phát triển thị trường bất động sản. Để sử dụng, khai thác nguồn nội lực quan trọng này, việc liên tục tìm kiếm các giải pháp thúc đẩy thị trường Bất Động Sản (BĐS) phát triển ổn định, lành mạnh là một vấn đề quan trọng và mang tính chiến lược của quốc gia, đặc biệt là các giải pháp nhằm hoàn thiện khung pháp lý điều chỉnh thị trường.

Quá trình phát triển dự án BĐS thể hiện mối quan hệ giữa các chủ thể: Nhà nước; chủ đầu tư thực hiện dự án; người dân. Trong đó Nhà nước (bao gồm các cơ quan quản lý nhà nước) thực hiện hoạt động quản lý nhà nước đối với các hoạt động đầu tư, thực hiện dự án bất động sản như: quyết định chủ trương đầu tư dự án; quyết định giao đất, cho thuê đất, chuyển mục đích sử dụng đất thực hiện dự án; cấp giấy phép xây dựng nhà ở, công trình xây dựng thuộc dự án... Chủ đầu tư dự án là các tổ chức, cá nhân đầu tư vốn, sử dụng vốn đầu tư để thực hiện việc lập đề xuất đầu tư dự án; thực hiện các thủ tục pháp lý cho việc đầu tư dự án; tổ chức thi công, xây dựng các công trình tại dự án; thực hiện phân phối sản phẩm bất động sản... Với vai trò quản lý nhà nước đối với thị trường $\mathrm{BĐS}$, thông qua pháp luật và cơ chế chính sách, Nhà nước thực hiện giải quyết hài hòa mối quan hệ giữa lợi ích quốc gia, lợi ích chính đáng của chủ đầu tư dự án và lợi ích của người dân. Việc lựa chọn và công nhận chủ đầu tư thực hiện dự án chính là một trong những công tác thể hiện vai trò quản lý nhà nước đối với thị trường $\mathrm{BĐS.}$

Hoạt động lựa chọn chủ đầu tư thực hiện dự án là một giai đoạn vô cùng quan trọng và phải được thực hiện theo quy định pháp luật nhằm hướng tới một thị trường $\mathrm{BĐS}$ minh bạch và hiệu quả. Điều này bắt đầu từ sự hợp lý, hoàn chỉnh của khung pháp lý do Nhà nước ban hành đến tính nghiêm minh trong việc thực thi pháp luật của các chủ thể có liên quan. Trong thực tế, hoạt động lựa chọn chủ đầu tư thực hiện dự án của các cơ quan quản lý Nhà nước; việc đấu giá Quyền Sử Dụng (QSD) đất; đấu thầu dự án hay chỉ định chủ đầu tư dự án vẫn còn những vướng mắc, là nguyên nhân chủ yếu ảnh hưởng đến sự phát triển của thị trường BĐS hiện nay.

\section{Một số khái niệm liên quan đến hoạt động lựa chọn nhà đầu tư thực hiện dự án}

\subsection{Dụ án bất động sản}

Dự án bất động sản là hoạt động bỏ vốn đầu tư nhằm thiết lập mô hình kinh doanh trên một khu đất. Theo Luật kinh doanh bất động sản số 63/2006/QH11 (Quốc hội, 2006), "Hoạt động kinh doanh bất động sản là việc bỏ vốn đầu tu tạo lập, mua, nhận chuyển nhuợng, thuê, thuê mua bất động sản để bán, chuyển nhương, cho thuê, cho thuê lại, cho thuê mua nhằm mục đích sinh lợi".

\section{2. Đấu giá bất động sản}

Theo Luật kinh doanh bất động sản số 63/2006/QH11 (Quốc hội, 2006), “Đấu giá bất động 
sản là việc bán, chuyển nhương bất động sản công khai để chọn người mua, nhận chuyển nhương bất động sản trả giá cao nhất theo thủ tục đấu giá tài sản".

\section{3. Đấu thầu}

Theo Luật đấu thầu số 43/2013/QH13 (Quốc hội, 2013a), "Đấu thầu là quá trình lựa chọn nhà thầu để ký kết và thục hiện hợp đồng cung cấp dịch vụ tu vấn, dịch vu phi tu vấn, mua sắm hàng hóa, xây lắp; lựa chọn nhà đầu tu để ký kết và thực hiện hợp đồng dự án đầu tư theo hình thức đối tác công tư, dự án đầu tu có sử dụng đất trên cơ sở bảo đảm cạnh tranh, công bằng, minh bạch và hiệu quả kinh tế".

\subsection{Nhà ở thương mại}

Theo Luật Nhà ở số 65/2014/QH13 (Quốc hội, 2014a) thì "Nhà ở thuoong mại là nhà ở được đầu tu xây dụng để bán, cho thuê, cho thuê mua theo co chế thị trương". Như vậy có thể hiểu nhà ở thương mại là nhà ở được xây dựng, phát triển bởi chủ đầu tư với mục đích bán hoặc cho thuê, trong đó các điều kiện giao dịch sẽ do bên mua và bên bán thỏa thuận và thương lượng.

\section{thương mại}

3. Quy định pháp lý về trình tự, thủ tục lựa chọn chủ đầu tư dự án xây dựng nhà ở

Trình tự, thủ tục lựa chọn chủ đầu tư dự án xây dựng nhà ở thương mại được quy định tại điều 18, Nghị định số 99/2015/NĐ-CP (Bộ xây dựng, 2016a) và được sửa đổi, bổ sung bởi Nghị định số 30/2019/NĐ-CP ngày 28 tháng 3 năm 2019 của Chính phủ quy định chi tiết và hướng dẫn thi hành một số điều của Luật Nhà ở số 65/2014/QH13 (Quốc hội, 2014a).

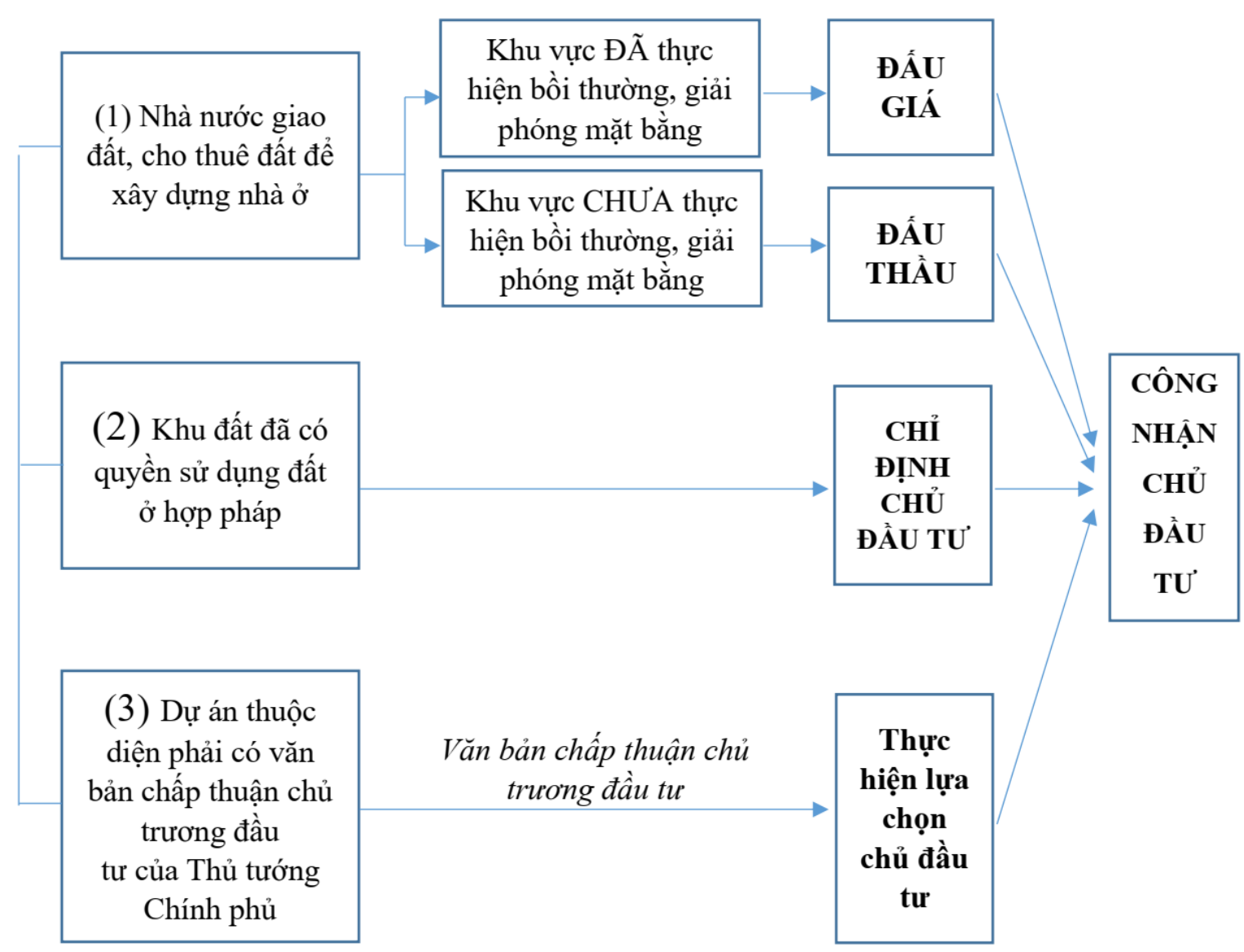

Hình 1. Hình thức lựa chọn chủ đầu tư dự án xây dựng nhà ở thương mại 


\subsection{Truò̀ng hơp 1}

Nhà nước giao đất, cho thuê đất để xây dựng nhà ở sẽ thực hiện lựa chọn chủ đầu tư theo hai trường hợp:

- Đối với khu vực đã thực hiện bồi thường, giải phóng mặt bằng thì lựa chọn chủ đầu tư thông qua hình thức đấu giá quyền sử dụng đất. Thời gian và quy trình đấu giá quyền sử dụng đất được thực hiện theo quy định của pháp luật về đất đai và pháp luật về đấu giá. Nếu khu đất đấu giá thuộc khu vực đã được quy hoạch để đầu tư xây dựng nhà ở theo dự án thì các tổ chức, cá nhân tham gia đấu giá quyền sử dụng đất tại khu vực này phải có đủ điều kiện làm chủ đầu tư dự án của Luật Nhà ở, Luật Đất đai và pháp luật về kinh doanh bất động sản.

- Đối với khu vực chưa thực hiện bồi thường, giải phóng mặt bằng thì lựa chọn chủ đầu tư thông qua hình thức đấu thầu nếu có nhiều nhà đầu tư có đủ điều kiện theo quy định tại Điều 21 của Luật Nhà ở đăng ký tham gia làm chủ đầu tư; trường hợp chỉ có một nhà đầu tư đủ điều kiện đăng ký tham gia thì chỉ định nhà đầu tư đó làm chủ đầu tư. Thời gian và quy trình đấu thầu lựa chọn chủ đầu tư dự án xây dựng nhà ở được thực hiện theo quy định của pháp luật về đấu thầu.

Trong cả hai trường hợp trên, UBND cấp tỉnh là cơ quan có thẩm quyền quyết định lựa chọn chủ đầu tư.

\subsection{Truò̀ng hơp 2}

Trường hợp tổ chức, cá nhân đã có QSD đất ở hợp pháp, phù hợp với quy hoạch xây dựng nhà ở, kế hoạch sử dụng đất đã được cơ quan có thẩm quyền phê duyệt, có đủ điều kiện làm chủ đầu tư theo quy định tại Điều 21 của Luật Nhà ở và có nhu cầu tham gia đầu tư xây dựng nhà ở thì Sở Xây dựng kiểm tra và báo cáo UBND cấp tỉnh quyết định giao cho nhà đầu tư đó làm chủ đầu tur.

\subsection{Truò̀ng hơp 3}

Trường hợp dự án thuộc diện phải có văn bản chấp thuận chủ trương đầu tư của Thủ tướng Chính phủ thì UBND cấp tỉnh phải làm thủ tục đề nghị Thủ tướng Chính phủ có văn bản chấp thuận chủ trương đầu tư trước khi thực hiện lựa chọn chủ đầu tư.

\subsection{Các hình thức lụa chọn chủ đầu tư}

\subsection{1. Đấu giá quyền sủ dụng đất}

Dự án đầu tư xây dựng nhà ở thuộc khu vực đã thực hiện bồi thường, giải phóng mặt bằng thì lựa chọn chủ đầu tư thực hiện dự án thông qua hình thức đấu giá QSD đất. Việc đấu giá QSD đất để lựa chọn chủ đầu tư thực hiện dự án đầu tư xây dựng nhà ở phải đảm bảo tính độc lập, trung thực, công khai, minh bạch, công bằng, khách quan; bảo vệ quyền, lợi ích của Nhà nước, của nhà đầu tư tham gia đấu giá, nhà đầu tư trúng đấu giá. Việc đấu giá QSD đất phải phải thực hiện theo đúng trình tự, thủ tục theo quy định của pháp luật về đất đai và pháp luật về đấu giá.

\subsection{2. Đấu thầu dự án có sử dụng đất}

Dự án đầu tư xây dựng nhà ở thuộc khu vực chưa thực hiện bồi thường, giải phóng mặt bằng thì lựa chọn chủ đầu tư thực hiện dự án thông qua hình thức đấu thầu dự án có sử dụng đất.

- Trường hợp chỉ có một nhà đầu tư trúng sơ tuyển thì thực hiện quy trình chỉ định nhà đầu tư (theo Nghị định số 25/2020/NĐ-CP quy định chi tiết thi hành một số điều của Luật đấu thầu, về lựa chọn nhà đầu tu (Chính phủ, 2020)).

- Trường hợp có hai nhà đầu tư trở lên trúng sơ tuyển hoặc đối với dự án có tổng chi phí thực hiện dự án dưới 120 tỷ đồng (không bao gồm chi phí bồi thường, giải phóng mặt bằng) thực 
hiện quy trình đầu thầu lựa chọn nhà đầu tư thực hiện dự án (theo Nghị định số 25/2020/NĐ-CP (Chính phủ, 2020)).

\subsubsection{Chỉ địh chủ đầu tu}

Truờng hợp chủ đầu tư có quyền sử dụng đất ở hợp pháp (theo quy định tại khoản 1 và khoản 4 điều 23 của Luật nhà ở) và có đủ điều kiện (quy định tại điều 21 của Luật nhà ở) thì được chỉ định là chủ đầu tư thực hiện dự án.

Nhà đầu tư lập bộ hồ sơ đăng ký làm chủ đầu tư dự án kèm theo giấy tờ chứng minh quyền sử dụng đất ở hợp pháp theo quy định của pháp luật và gửi về Sở xây dựng để trình UBND cấp tỉnh công nhận chủ đầu tư dự án.

\section{Thực trạng hoạt động lựa chọn nhà đầu tư và các vướng mắc về pháp lý dự án}

\subsection{Quy trình phát triển dụ án bất động sản}

Dự án bất động sản là hoạt động bỏ vốn đầu tư nhằm thiết lập mô hình kinh doanh trên một khu đất. Để phát triển một dự án BĐS, nhìn chung các nhà đầu tư dự án BĐS đều xây dựng một quy trình phát triển dự án nhằm thỏa mãn các quy định về pháp lý và mục tiêu hiệu quả kinh doanh. Tùy vào tính chất của từng loại dự án $\mathrm{BĐS}$ mà quy trình có thể thay đổi phù hợp, tuy nhiên trên góc độ thủ tục pháp lý của dự án thì quá trình phát triển một dự án BĐS thường bao gồm các bước theo trình tự sau:

\section{Bảng 1}

Trình tự phát triển một dự án bất động sản

\begin{tabular}{|c|c|c|}
\hline Trình tụ̣ & Hạng mục & Cơ sở pháp lý \\
\hline Bước 1 & Chấp thuận chủ trương đầu tư & $\begin{array}{l}\text { 1. Luật đất đai số 45/2013/QH13 (Quốc hội, } \\
\text { 2013b) } \\
\text { 2. Luật Nhà ở số 65/2014/QH13 (Quốc hội, } \\
\text { 2014a) }\end{array}$ \\
\hline Bước 2 & $\begin{array}{l}\text { Phát triển quỹ đất thực hiện dự án để } \\
\text { triển khai dự án (Đấu giá/Đầu thầu } \\
\text { quyền sử dụng đất/Quyền sử dụng đất } \\
\text { ở hợp pháp) }\end{array}$ & $\begin{array}{l}\text { 1. Luật đấu thầu số 43/2013/QH13 (Quốc hội, } \\
\text { 2013a) } \\
\text { 2. Luật đấu giá số } 01 / 2016 / \mathrm{QH} 14 \text { (Quốc hội, } \\
\text { 2016) } \\
\text { 3. Luật đất đai số 45/2013/QH13 (Quốc hội, } \\
\text { 2013b) } \\
\text { 4. Nghị định 43/2014/NĐ-CP hướng dẫn thi hành } \\
\text { Luật đất đai (Chính phủ, 2014a) }\end{array}$ \\
\hline Bước 3 & Công nhận chủ đầu tư dự án & $\begin{array}{l}\text { 1. Luật đất đai số 45/2013/QH13 (Quốc hội, } \\
\text { 2013b) } \\
\text { 2. Nghị định 43/2014/NĐ-CP hướng dẫn thi hành } \\
\text { Luật đất đai (Chính phủ, 2014a) } \\
\text { 3. Luật Nhà ở số 65/2014/QH13 (Quốc hội, } \\
\text { 2014a) } \\
\text { 4. Nghị định 99/2015/NĐ-CP hướng dẫn thi hành } \\
\text { Luật nhà ở (Chính phủ, 2015a) } \\
\text { 5. Thông tư 19/2016/TT-BXD (Bộ xây dựng, } \\
\text { 2016a) }\end{array}$ \\
\hline
\end{tabular}




\begin{tabular}{|c|c|c|}
\hline Bước 4 & $\begin{array}{l}\text { Phê duyệt quy hoạch chi tiết xây } \\
\text { dựng } 1 / 500\end{array}$ & $\begin{array}{l}\text { 1. Luật Quy hoạch số 30/2009/QH12 (Quốc hội, } \\
\text { 2009) }\end{array}$ \\
\hline Bước 5 & $\begin{array}{l}\text { Quyết định giao đất/chuyển mục đích } \\
\text { sử dụng đất }\end{array}$ & $\begin{array}{l}\text { 1. Luật đất đai số 45/2013/QH13 (Quốc hội, } \\
\text { 2013b) } \\
\text { 2. Nghị định 43/2014/NĐ-CP hướng dẫn thi hành } \\
\text { Luật Đất đai (Chính phủ, 2014a) }\end{array}$ \\
\hline Bước 6 & Thực hiện nghĩa vụ tài chính & $\begin{array}{l}\text { 1. Luật đất đai số 45/2013/QH13 (Quốc hội, } \\
\text { 2013b) } \\
\text { 2. Nghị định 45/2014/NĐ-CP quy định về thu tiền } \\
\text { sử dụng đất (Chính phủ, 2014b) }\end{array}$ \\
\hline Bước 7 & $\begin{array}{l}\text { Xin phép xây dựng bao gồm thiết kế } \\
\text { cơ sở và thâm tra thiết kề xây dựng }\end{array}$ & $\begin{array}{l}\text { 1. Luật xây dựng số 50/2014/QH13 (Quốc hội, } \\
\text { 2014b) } \\
\text { 2. Nghị định 59/2015/NĐ-CP về quản lý dự án } \\
\text { đầu tư xây dựng (Chính phủ, 2015b) } \\
\text { 3. Nghị định 53/2017/NĐ-CP quy định các loại } \\
\text { giầy tờ hợp pháp để cấp phép xây dựng } \\
\text { 4. Thông tư 15/2016/TT-BXD (Bộ xây dựng, } \\
\text { 2016b) }\end{array}$ \\
\hline
\end{tabular}

Nguồn: Kết quả phân tích dữ liệu của nhóm nghiên cứu

Toàn bộ quy trình phát triển một dự án BĐS được điều chỉnh bởi nhiều văn bản pháp lý có liên quan. Các dự án nhà ở thương mại thường mất một khoảng thời gian dài để có thể đưa sản phẩm ra thị trường, trong đó mất khoảng hai đến ba năm để nhận chuyển nhượng QSD đất, bồi thường giải phóng mặt bằng; khoảng một đến hai năm để thực hiện các thủ tục đầu tư như chấp thuận chủ trương đầu tư, phê duyệt quy hoạch chi tiết tỷ lệ $1 / 500$, quyết định công nhận chủ đầu tư; hoàn thành nghĩa vụ tài chính để được cấp giấy chứng nhận QSD đất; và mất khoảng hai đến ba năm để triển khai xây dựng các công trình trong dự án. Với quy trình này thì việc công nhận chủ đầu tư dự án là một giai đoạn vô cùng quan trọng và được bắt đầu từ việc đấu giá QSD đất, đấu thầu dự án hay chỉ định chủ đầu tư dự án nhà ở thương mại là một trong những vướng mắc rất lớn và cũng là nguyên nhân chủ yếu gây ách tắc thị trường $\mathrm{BĐS}$ hiện nay.

Với quy định của Nghị định 99/2015/NĐ-CP (Chính phủ, 2015a), tùy từng trường hợp cụ thể mà việc lựa chọn chủ đầu tư sẽ được thực hiện bằng các hình thức khác nhau (Hình 1$)$. Với quan điểm hướng đến hoàn thiện quy trình thực hiện dự án nhà ở thương mại theo quy định của Luật Đầu tư và Luật Nhà ở, dựa trên ý kiến của các sở ngành và đơn vị dự Hội nghị "Gặp gõ và trao đổi giữa lãnh đạo chính quyền thành phố với doanh nghiệp kinh doanh bất động sản" tổ chức ngày 22/02/2020, Sở Xây dựng Thành phố Hồ Chí Minh (TPHCM) đã báo cáo và kiến nghị UBND thành phố thống nhất quy trình thực hiện dự án nhà ở thương mại theo quy định của Luật Đầu tư nhằm tăng cường tính minh bạch của thị trường bất động sản TPHCM.

\subsubsection{Truờng hợp nhà đầu tư chưa có quyền sử dụng đất họp pháp}

Khi nhà đầu tư chưa có QSD đất ở hợp pháp, việc lập thủ tục quyết định chủ trương đầu tư theo quy định của Luật Đầu tư được giao Sở Kế hoạch và Đầu tư phối hợp cùng Tổ chuyên gia (do Sở Kế hoạch và Đầu tư làm Tổ trưởng, thành viên gồm các sở, ngành, quận huyện có liên quan) xem xét, thẩm định hồ sơ, trình Ủy ban nhân dân thành phố ban hành Quyết định chủ trương đầu tư theo quy định và thẩm quyền được giao trong Luật Đầu tư và các Nghị định hướng dẫn thi hành. Sau khi có quyết định chủ trương đầu tư, nhà đầu tư (theo Luật Đầu tư) lập hồ sơ quy hoạch chi tiết tỷ lệ 1/500 hoặc thỏa thuận quy hoạch tổng mặt bằng phương án kiến trúc công trình, giao 
Sở Quy hoạch - Kiến trúc, Ủy ban nhân dân quận/huyện (theo thẩm quyền) tham mưu và tổ chức thực hiện theo quy định.

\section{Bảng 2}

Quy trình thực hiện dự án nhà ở thương mại đối với trường hợp nhà đầu tư chưa có quyền sử dụng đất ở hợp pháp

\begin{tabular}{|c|l|l|l|}
\hline Bước & \multicolumn{1}{|c|}{ Nội dung } & \multicolumn{1}{|c|}{ Căn cứ pháp lý } & \multicolumn{1}{|c|}{ Đơn vị phụ trách } \\
\hline 1 & $\begin{array}{l}\text { Lập thủ tục quyết định chủ trương đầu } \\
\text { tư }\end{array}$ & $\begin{array}{l}\text { Theo quy định của } \\
\text { Luật Đâuu tư }\end{array}$ & Sở Kế hoạch và Đầu tư \\
\hline 2 & $\begin{array}{l}\text { Lập quy hoạch chi tiết tỷ lệ 1/500 hoặc } \\
\text { thỏa thuận quy hoạch tông mặt bằng } \\
\text { phương án kiến trúc công trình }\end{array}$ & $\begin{array}{l}\text { Theo quy định của } \\
\text { Luật Quy hoạch đô } \\
\text { thị }\end{array}$ & $\begin{array}{l}\text { Sở Quy hoạch-Kiến trúc } \\
\text { UBND quận/huyện }\end{array}$ \\
\hline 3 & $\begin{array}{l}\text { Lập thủ tục giao thuê đất, chuyển mục } \\
\text { đích sử dụng đất }\end{array}$ & $\begin{array}{l}\text { Theo quy định của } \\
\text { Luật Đất đai }\end{array}$ & $\begin{array}{l}\text { Sở Tài nguyên và Môi } \\
\text { trường }\end{array}$ \\
\hline 4 & $\begin{array}{l}\text { Xác định nghĩa vụ tài chính, nộp tiền sử } \\
\text { dụng đất, cấp Giấy chứng nhận QSD } \\
\text { đất. }\end{array}$ & $\begin{array}{l}\text { Sở Tài nguyên và Môi } \\
\text { trường chủ trì } \\
\text { Sở Tài chính }\end{array}$ \\
\hline 5 & $\begin{array}{l}\text { Công nhận chủ đầu tư, chấp thuận đầu } \\
\text { tư, thầm định thiết kế cơ sở, thiết kế kỹ } \\
\text { thuật, cấp Giấy phép xây dựng }\end{array}$ & Sở Xây dựng \\
\hline
\end{tabular}

Nguồn: Công văn 2363/SXD-PTĐT của Sở xây dựng TPHCM (Sở xây dựng TPHCM, 2020)

\subsubsection{Truờng hợp nhà đầu tư đã có quyền sủ dụng đất hợp pháp}

Như vậy, theo Công văn 2363/SXD-PTĐT (Sở xây dựng TPHCM, 2020) của Sở xây dựng TPHCM thì trong cả hai trường hợp, việc công nhận chủ đầu tư chỉ có thể được thực hiện sau khi đã có văn bản chấp thuận chủ trương đầu tư. Nhưng trên thực tế thì có nhiều dự án nhà ở thương mại trên địa bàn thành phố có nguồn gốc đất do đền bù đất nông nghiệp hoặc đất chuyên dùng, đã có văn bản công nhận chủ đầu tư của UBND Thành phố nhưng chưa có văn bản chấp thuận đầu tư, chưa thực hiện thủ tục thu hồi, giao đất, chuyển mục đích sử dụng đất theo quy định (theo Danh mục Nhà ở thương mại có nguồn gốc đất do đền bù đất nông nghiệp hoặc sư dụng đất chuyên dùng - Ban hành kèm theo Công văn 1225/UBND-ĐT ngày 04 tháng 4 năm 2020 của UBND thành phố (Ủy ban nhân dân thành phố Hồ Chí Minh, 2020)). Đây là một vướng mắc lớn về pháp lý thể hiện sự lúng túng của những đối tượng có liên quan đến dự án, gây đọng vốn và giảm hiệu quả kinh doanh của các chủ đầu tư khi phải tạm dừng dự án để thực hiện rà soát lại về thủ tục pháp lý liên quan đến lựa chọn nhà đầu tư theo đúng quy định.

\subsection{Một số vướng mắt pháp lý trong hoạt động lựa chọn nhà đầu tư thục hiện dụ án}

\subsubsection{Khái niệm về "đất công” chưa được quy định cu thể trong văn bản pháp lý}

Hiện nay khái niệm "đất công" chưa được quy định cụ thể trong các văn bản pháp luật dẫn đến chưa thống nhất việc hiểu thế nào là "đất công" nên tồn tại sự lúng túng trong việc thực thi các quy định pháp luật có liên quan đến loại đất này, chưa quy định cụ thể về quyền và nghĩa vụ của các đối tượng có liên quan đến loại “đất công” này. Cụ thể, trong hệ thống phân loại đất của Luật Đất đai và các nghị định, thông tư quy định chi tiết thi hành Luật Đất đai không có loại “đất công" và cũng không quy định chế độ quản lý, sử dụng đất, quyền và nghĩa vụ của người sử dụng “đất công”. 


\subsubsection{Chura quy định chi tiết các tiêu chí thực hiện đấu thầu lựa chọn nhà đầu tu cho dụ} án nhà ở xã họi

Tại các đô thị lớn có nhu cầu lớn về nhà ở xã hội, đồng thời đây là cũng chủ trương của Nhà nước về xã hội hóa đầu tư xây dựng nhà ở xã hội. Tuy nhiên, hiện tại Nghị định 25/2020/NĐ$\mathrm{CP}$ quy định chi tiết thi hành một số điều của Luật đấu thầu về lựa chọn nhà đầu tư chưa quy định chi tiết các tiêu chí thực hiện đấu thầu lựa chọn nhà đầu tư cho dự án nhà ở xã hội đối với “ $k h u$ đất do Nhà nước đang quản lý" được quy hoạch xây dựng nhà ở xã hội. Vì vậy khi các địa phương muốn thực hiện đấu thầu dự án có sử dụng đất để lựa chọn chủ đầu tư dự án nhà ở xã hội sẽ có nhiều lúng túng do Khoản 4 Điều 12 Nghị định 25/2020/NĐ-CP chưa quy định chi tiết các tiêu chí thực hiện đấu thầu lựa chọn nhà đầu tư dự án nhà ở xã hội, điều này có thể gây lãng phí quỹ đất công và không thực hiện được chủ trương xã hội hóa đầu tư xây dựng nhà ở xã hội.

4.2.3. Vuớng mắc về đất Nhà nước quản lý trong các dụ án liên quan đến đất công xen cài trong các dụ án nhà ở

Hiện nay tại nhiều địa phương tồn đọng các dự án bất động sản chưa thể triển khai do còn nhiều vướng mắc liên quan đến phần đất công, nhiều dự án phải tạm dừng đề rà soát các quy định pháp lý liên quan đến phần đất công do Nhà nước quản lý nằm xen cài trong các dự án và phải thực hiện đấu thầu hoặc đấu giá đúng quy định.

Phần lớn các dự án (nhà ở, sản xuất kinh doanh, công trình công cộng) được thực hiện trên khu đất có diện tích lớn, được hợp lại từ nhiều thửa đất do các hộ gia đình, cá nhân sử dụng mà chủ đầu tư thỏa thuận bồi thường, nhận chuyển nhượng hoặc Nhà nước thực hiện thu hồi. Xen cài giữa các thửa đất do hộ gia đình, cá nhân sử dụng có một phần đất công cộng (thường gọi là “đất công”) như đường đi vào các thửa đất hộ dân, kênh rạch... khi phê duyệt quy hoạch chi tiết 1/500 đã không giữ nguyên mục đích của diện tích đất công này mà được bố trí lại cho hợp lý. Như vậy, diện tích đất này cần được giao cho nhà đầu tư để thực hiện dự án theo quy hoạch.

Tại TPHCM, trước đây khi nhà đầu tư được giao phần diện tích "đất công" để thực hiện dự án, ngoài nộp tiền sử dụng đất theo diện tích, cơ cấu sử dụng đất theo quy định, nhà đầu tư còn phải thực hiện bồi thường do sử dụng "đất công" theo phương thức hoán đổi đất ở đã có hạ tầng để bố trí tái định cư hoặc nhà đầu tư nộp bằng tiền vào ngân sách nếu không còn quỹ đất ở tại dự án để thực hiện hoán đổi. Tuy nhiên, theo Điều 118 và 119 Luật Đất đai năm 2013 thì diện tích đất Nhà nước trực tiếp quản lý nêu trên thuộc trường hợp phải đấu giá QSD đất. Thực tế, việc đấu giá QSD đất là khó thực hiện vì phần diện tích đất này có diện tích nhỏ, hình thể không phù hợp để thực hiện một dự án độc lập mà nằm xen cài giữa các thửa đất nhà đầu tư đã nhận chuyển nhượng hay nhận góp vốn để chuyển mục đích sử dụng đất, nhưng nếu giao cho nhà đầu tư diện tích đất này để kết hợp với diện tích đất nhà đầu tư đã có thì được xem như giao chỉ định, không phù hợp với quy định hiện hành. Để giải quyết vướng mắc này, TPHCM đã kiến nghị Bộ Tài nguyên và Môi trường có ý kiến hướng dẫn về hình thức giao đất, cho thuê đất đối với diện tích đất nhà nước quản lý trong những trường hợp này.

\subsubsection{Vướng mắc trong sử dụng đất do thực hiện cổ phần hóa doanh nghiệp Nhà nước}

Khi thực hiện cổ phần hóa doanh nghiệp Nhà nước phải xác định lại giá trị QSD đất để tính vào giá trị doanh nghiệp đối với diện tích đất đã được giao, đã nộp tiền sử dụng đất cho ngân sách Nhà nước. Trong quá trình cổ phần hóa, doanh nghiệp đã được xác định giá trị tài sản trên đất để tính vào phần vốn nhà nước mà chưa xác định giá trị QSD đất nên doanh nghiệp phải thực hiện thuê đất ngắn hạn do không còn phù hợp với quy quy hoạch sử dụng đất và không được cấp Giấy chứng nhận QSD đất, sau đó chuyển nhượng cho đơn vị khác dẫn đến thất thoát vốn nhà nước trong doanh nghiệp cổ phần hóa. 
Trong quá trình triển khai cổ phần hóa, nhiều doanh nghiệp cổ phần hóa và cơ quan quản lý nhà nước còn lúng túng trong triển khai phương án sắp xếp lại, xử lý nhà, đất theo quy định của pháp luật về quản lý, sử dụng tài sản công và phương án sử dụng đất sau cổ phần hóa. Ủy ban nhân dân TPHCM đã có công văn gửi Bộ Tài nguyên và Môi trường đề nghị làm rõ trường hợp xin chuyển mục đích sử dụng đất để thực hiện dự án nhà ở đối với đất đang thuộc quyền quản lý, sử dụng của doanh nghiệp cổ phần hóa có cần xem xét quyết định chủ chương đầu tư hay phải thu hồi bán đấu giá. Tại công văn số 2218/BTNMT-TCQLĐĐ ngày 22/4/2020 (Bộ tài nguyên môi trường, 2020) trả lời về các vướng mắc của TPHCM, Bộ Tài nguyên và Môi trường đã đề nghị thực hiện đúng quy định tại Điểm i Khoản 1 Điều 2 Nghị quyết số 60/2018/QH14 của Quốc hội về tiếp tục hoàn thiện và đẩy mạnh việc thực hiện chính sách, pháp luật về quản lý, sử dụng vốn, tài sản Nhà nước tại doanh nghiệp và cổ phần hóa doanh nghiệp Nhà nước.

Như vậy, có thể xác định khu đất mà doanh nghiệp chưa được cấp Giấy chứng nhận QSD đất thì không có cơ sở để chia tách. Trường hợp giải quyết cho doanh nghiệp được chia tách sử dụng đất, sau đó doanh nghiệp này chuyển mục đích sử dụng đất, thực hiện dự án theo quy hoạch thì có phù hợp hay không, có bị thất thoát vốn nhà nước hay không? Tại Điểm i Khoản 4 Điều 95 Luật Đất đai thì việc chia tách QSD đất của tổ chức được thực hiện khi tổ chức sử dụng đất đã được cấp giấy chứng nhận QSD đất. Do đó, trường hợp doanh nghiệp chưa được cấp giấy chứng nhận QSD đất thì không có cơ sở để công nhận QSD đất cho doanh nghiệp sau khi được chia tách.

4.2.5. Quyền sủ dụng đất ở hợp pháp khi công nhận chủ đầu tu nhà ở thương mại có nguồn gốc đất do đền bù đất nông nghiệp hoạc đất chuyên dùng

Theo báo cáo của Sở Xây dựng TPHCM, từ tháng 12/2015 Nghị định 99/2015/NĐ-CP (Chính phủ, 2015a) đã có hiệu lực, UBND Thành phố đã chấp thuận chủ trương đầu tư, công nhận chủ đầu tư cho 63 dự án nhà ở thương mại có nguồn gốc đất do đền bù đất nông nghiệp hoặc đất chuyên dùng. Các dự án này được xác định là đất ở theo đồ án quy hoạch được duyệt. Trong đó, có 03 (ba) dự án đã có văn bản của cơ quan có thẩm quyền cho phép chuyển mục đích sử dụng đất để triển khai dự án xây dựng nhà ở; 02 (hai) dự án đã có quyết định thu hồi đất khi thực hiện giải phóng mặt bằng để đầu tư xây dựng nhà ở. Tuy nhiên, theo quy định truờng hợp chủ đầu tư có quyền sử dụng đất ở hợp pháp (theo quy định tại khoản 1 và khoản 4 điều 23 của Luật nhà ở) và có đủ điều kiện (quy định tại điều 21 của Luật nhà ở) thì được chỉ định là chủ đầu tư thực hiện dự án. Nghĩa là, phải có $100 \%$ đất ở thì mới được chỉ định chủ đầu tư dự án nhà ở thương mại. Đây chính là một "điểm nghẽn” đối với việc phát triển các dự án nhà ở thương mại tại TPHCM. Liên quan đến vấn đề này, tại công văn số 2218/BTNMT-TCQLĐĐ (Bộ tài nguyên môi trường, 2020) ngày 22/4/2020, Bộ Tài nguyên và môi trường thống nhất với đề xuất của UBND TPHCM: “đối với diện tích đất thuộc diện có nguồn gốc đất do đền bù đất nông nghiệp hoạc đất chuyên dùng, nếu đã có văn bản của cơ quan có thẩm quyền cho phép chuyển muc đích sử dụng đất để triển khai dư án nhà ở hoặc được ghi trong quyết định thu hồi đất là để thực hiện dụ án thì diện tích đất đó được coi là đất ở theo đúng quy định pháp luật và được co quan Nhà nuớc có thẩm quyền cho phép thưc hiện theo quy dịnh pháp luật". Ngoài ra, Bộ Tài nguyên và môi trường cũng giải thích: "đối với diện tích đất thuộc diện có nguồn gốc đất do đền bù đất nông nghiệp hoạc đất chuyên dùng, nếu được xác định là đất ở theo đồ án quy hoạch được duyệt thì diện tích đất đó được coi là đất ở là chura có cơ sở vì đồ án quy hoạch của dư án được phê duyệt không phải là quyết định của co quan Nhà nước có thẩm quyền cho phép chuyển muc đích sử dụng đất, không phải là quyết định giao đất, cho thuê đất của cấp có thẩm quyền theo quy định của pháp luật về đất đai".

\subsubsection{Sụ công khai, minh bạch trong đấu thầu, đấu giá đất công}

Việc đấu giá quyền sử dụng đất, đấu thầu dự án có sử dụng đất là vấn đề được dư luận quan 
tâm trong thời gian qua. Nguyên nhân chính cho vấn đề này là nhiều trường hợp được giao đất, chỉ định chủ đầu tư thực hiện dự án không qua đấu giá/đấu thầu công khai dẫn đến thất thu lớn cho ngân sách Nhà nước. Ngoài ra, việc đề ra khung giá đất không sát với giá thị trường còn dẫn đến nhiều tiêu cực liên quan đến đất đai, ảnh hưởng đến niềm tin của nhân dân vào vai trò quản lý của các cơ quan Nhà nước.

Trong quá trình Việt Nam hội nhập với kinh tế quốc tế với kỳ vọng sẽ gia tăng thu hút vốn FDI, trong đó có lĩnh vực bất động sản, tuy nhiên nếu tính minh bạch thông tin chưa cao sẽ gây khó khăn cho việc thu hút vốn đầu tư nước ngoài vào thị trường $\mathrm{BĐS} \mathrm{Việt} \mathrm{Nam.} \mathrm{Mặc} \mathrm{dù} \mathrm{chỉ} \mathrm{số}$ minh bạch của thị trường $\mathrm{BĐS}$ nước ta đã có thay đổi đáng kể trong thời gian qua nhưng sự cải thiện này là chưa đủ, cần đẩy mạnh hơn nữa việc minh bạch thông tin trên thị trường. Chính vì thế, việc thay đổi về mặt thể chế có ý nghĩa đặc biệt quan trọng trong việc đấu giá/đấu thầu đất công theo hướng công khai, rõ ràng nhằm phát triển một thị trường $\mathrm{BĐS}$ có tính hiệu quả và tính minh bạch cao.

\section{Khuyến nghị và kết luận}

\subsection{Khuyến nghị}

Trên cơ sở những vướng mắc và tồn tại trong quá trình thực thi các quy định pháp lý về hoạt động lựa chọn chủ đầu tư thực hiện dự án, bài viết có một số khuyến nghị nhằm tháo gỡ các khó khăn, đảm bảo tính pháp lý của các dự án, hướng đến một thị trường BĐS hiệu quả và minh bạch hơn, bao gồm:

- Nhằm thống nhất và cụ thể hóa các quy định pháp lý có liên quan đến loại đất công, Bộ Tài nguyên và Môi trường nên hướng dẫn hoặc trình Chính phủ quy định cụ thể về loại đất này cũng như quy định cụ thể quyền và nghĩa vụ của chủ thể có liên quan đến việc sử dụng loại đất này.

- Xây dựng quy trình phê duyệt hợp lý đối với trường hợp dự án nhà ở xã hội phải có văn bản chấp thuận chủ trương đầu tư của Thủ tướng Chính phủ, bởi theo quy định tại Điểm a Khoản 7 Điều 1 "Dự thảo Nghị định" sửa đổi, bổ sung điểm a Khoản 3 Điều 8 Nghị định 100/2015/NĐ$\mathrm{CP}$ nhà đầu tư phải lên Bộ Xây dựng hai lần để làm thủ tục. Trường hợp dự án nhà ở xã hội phải có văn bản chấp thuận chủ trương đầu tư của Thủ tướng Chính phủ thì Ửy ban nhân dân cấp tỉnh có văn bản trình Thủ tướng Chính phủ có văn bản chấp thuận chủ trương đầu tư, đồng thời đề xuất nhà đầu tư. Bộ Xây dựng xem xét về sự phù hợp với chương trình, kế hoạch phát triển nhà ở; yêu cầu đối với dự án và điều kiện của chủ đầu tư trước khi trình Thủ tướng Chính phủ có văn bản chấp thuận chủ trương đầu tư.

- Nhằm giải quyết các vướng mắc về đất Nhà nước quản lý trong các dự án liên quan đến đất công xen cài trong các dự án nhà ở, Chính phủ cần hướng dẫn, chỉ đạo nhằm giải quyết các vướng mắc pháp lý đối với quỹ đất công có tổng diện tích dưới $1.000 \mathrm{~m}^{2}$ do Nhà nước quản lý nằm trong các dự án nhà ở thì cho phép thành phố giao cho chủ đầu tư để chuyển mục đích sử dụng đất và thực hiện theo quy hoạch nhưng phải phù hợp với quy hoạch, kế hoạch sử dụng đất và khi giao đất, cho thuê đất phải xác định giá đất cụ thể. Trường hợp quỹ đất này có tổng diện tích đất công trên $1.000 \mathrm{~m}^{2}$ thì cho thành phố hoán đổi với chủ đầu tư để có quỹ đất tương đương, tập trung ngay tại dự án Nhà nước quản lý, sử dụng. Để giải quyết thấu đáo và phù hợp thực tiễn, Bộ Tài nguyên và Môi trường nên đề xuất Thủ tướng Chính phủ cho bổ sung đề xuất này vào "Nghị định sưa đổi, bổ sung một số điều của các Nghị định thi hành Luật Đất đai", trong đó có cơ chế xử lý các thửa đất do Nhà nước quản lý nằm xen cài trong dự án nhà ở thương mại, để tái khởi động các dự án nhà ở đang bị tạm dừng thực hiện để rà soát thủ tục pháp lý.

- Bộ Tài nguyên và môi trường cần tổng hợp ý kiến của các địa phương để báo cáo cấp 
thẩm quyền xem xét, quyết định trong quá trình triển khai Nghị quyết số 60/2018/QH14 của Quốc hội về tiếp tục hoàn thiện và đẩy mạnh việc thực hiện chính sách, pháp luật về quản lý, sử dụng vốn, tài sản Nhà nước tại doanh nghiêp và cổ phần hóa doanh nghiệp Nhà nước.

- Tất cả các dự án cần đảm bảo có QSD đất ở hợp pháp khi công nhận chủ đầu tư nhà ở thương mại có nguồn gốc đất do đền bù đất nông nghiệp hoặc đất chuyên dùng Như vậy đối với các dự án đang có vướng mắc về vấn đề này, nhà đầu tư sẽ phải thực hiện lại thủ tục quyết định chủ trương đầu tư theo quy định của Luật Đầu tư và công nhận chủ đầu tư theo Luật Nhà ở, phải hủy bỏ các quyết định thu hồi, giao đất hoặc chuyển mục đích sử dụng đất hoặc Nhà nước phải hoàn trả nghĩa vụ tài chính mà chủ đầu tư đã thực hiện.

Nhằm đẩy mạnh hơn nữa tính minh bạch thông tin trên thị trường bất động sản, việc thay đổi về mặt thể chế có ý nghĩa đặc biệt quan trọng trong việc đấu giá/đấu thầu đất công theo hướng công khai, rõ ràng nhằm phát triển một thị trường bất động sản có tính hiệu quả và tính minh bạch cao.

\subsection{Kết luận}

Một trong những nguyên nhân dẫn đến những tồn tại trong hoạt động lựa chọn nhà đầu tư thực hiện dự án là các quy định pháp luật chưa có sự thống nhất trong quá trình chuyển tiếp và ban hành. Nhiều dự án trong quá trình kiểm tra, kiểm toán, điều tra rà soát thủ tục pháp lý dẫn đến tình trạng ách tắc trong quá trình giải quyết của các cơ quan nhà nước, chưa đảm bảo một quy trình liên thông, đồng bộ. Điều này cho thấy thị trường bất động sản tại Việt Nam cần được quản lý và kiểm soát một cách hiệu quả hơn, kỳ vọng này xuất phát từ việc hoàn thiện khung pháp lý. Nếu không có giải pháp tháo gỡ vướng mắc kịp thời trong thủ tục, quy trình lựa chọn nhà đầu tư dự án sẽ tác động trực tiếp đến thị trường, gây khó khăn cho doanh nghiệp bất động sản, dẫn đến giảm nguồn thu ngân sách nhà nước từ các hoạt động đầu tư, xây dựng và kinh doanh bất động sản. Đây là một thách thức không nhỏ đối với sự phát triển của thị trường bất động sản Việt Nam trong tương lai.

\section{Tài liệu tham khảo}

Bộ Tài nguyên môi trường. (2014). Thông tư 24/2014/TT-BTNMT ngày 19 tháng 05 năm 2014 của Bộ Tài nguyên và Môi trương quy định về hồ so địa chính [Circular 24/2014/TT-BTNMT dated 19 May 2014 the Ministry of Natural Resources and Environment regulating cadastral records]. $\quad$ Retrieved October 10, 2019, from https://thuvienphapluat.vn/van-ban/Bat-dong-san/Thong-tu-24-2014-TT-BTNMT-ho-so-diachinh-236560.aspx

Bộ Tài nguyên môi trường. (2019). Công văn số 3886/BTNMT-TCQLĐĐ ngày 13 tháng 8 năm 2019 của Bộ Tài nguyên và Môi trương về việc trả lời vướng mắc, kiến nghị trong lĩnh vực đất đai trên địa bàn Thành phố Hồ Chí Minh [Official dispatch 3886/BTNMT-TCQLDD dated 13 August 2019 of the Ministry of Natural Resources and Environment on answering questions and proposals in the field of land in Ho Chi Minh City]. Retrieved October 5, 2019, from https://thuvienphapluat.vn/cong-van/Bat-dong-san/Cong-van-3886-BTNMT-TCQLDD2019-vuong-mac-trong-linh-vuc-dat-dai-thanh-pho-Ho-Chi-Minh-443414.aspx

Bộ tài nguyên môi trường. (2020). Công văn số 2218/BTNMT-TCQLĐĐ ngày 22/4/2020 của Bộ Tài nguyên và Môi trường về việc trả lời các vuóng mắc của TPHCM [Official dispatch 2218/BTNMT-TCQLDD dated 22 April 2020 of the Ministry of Natural Resources and Environment on answering questions of Ho Chi Minh City]. Retrieved October 6, 2019, from https://thuvienphapluat.vn/cong-van/Bat-dong-san/Cong-van-3886-BTNMT-TCQLDD2019-vuong-mac-trong-linh-vuc-dat-dai-thanh-pho-Ho-Chi-Minh-443414.aspx 
Bộ xây dựng. (2016a). Thông tu 19/2016/TT-BXD ngày 30 tháng 6 năm 2016 của Bộ Xây dụng Huoóng dẫn thực hiện một số nội dung của Luật Nhà ở và Nghị định số 99/2015/NĐ-CP ngày 20 tháng 10 năm 2015 của Chính phủ quy dịnh chi tiết và hướng dẫn thi hành một số điều của Luât nhà ở [Circular 19/2016/TT-BXD dated 30 June 2016 of the Ministry of Construction guiding the implementation of some contents of the Law on Housing and Decree No. 99/2015/ND-CP dated 20 October 2015 of the Ministry of Construction. Government details and guides the implementation of a number of articles of the Housing Law]. Retrieved October 15, 2019, from https://luatminhkhue.vn/thong-tu-19-2016-tt-bxd-huong-dan-99-2015-ndcp-luat-nha-o.aspx

Bộ xây dựng. (2016b). Thông tu 15/2016/TT-BXD ngày 30 tháng 06 năm 2016 của Bộ Xây dụng Hương dẫn về cấp giấy phép xây dưng [Circular 15/2016/TT-BXD dated 30 June 2016 of the Ministry of Construction guiding to building permits]. Retrieved October 15, 2019, from https://thuvienphapluat.vn/van-ban/Xay-dung-Do-thi/Thong-tu-15-2016-TT-BXD-capgiay-phep-xay-dung-quan-ly-trat-tu-xay-dung-291676.aspx

Chính phủ. (2014a). Nghị định 43/2014/NĐ-CP ngày 15 tháng 05 năm 2014 của Chính phủ Quy định chi tiết thi hành một số điều của Luật đất đai [Decree 43/2014/ND-CP dated 15 May 2014 of the Government detailing the implementation of a number of articles of the Land Law]. Retrieved October 16, 2019, from https://thuvienphapluat.vn/van-ban/Bat-dong-san/Nghidinh-43-2014-ND-CP-huong-dan-thi-hanh-Luat-Dat-dai-230680.aspx

Chính phủ. (2014b). Nghị định 45/2014/NĐ-CP ngày 15 tháng 05 năm 2014 của Chính phủ Quy dịnh về thu tiền sư dụng đất [Decree 45/2014/ND-CP dated 15 May 2014 of the Government on regulations on collection of land use fees]. Retrieved October 17, 2019, from https://thuvienphapluat.vn/van-ban/Bat-dong-san/Nghi-dinh-45-2014-ND-CP-thu-tien-sudung-dat-234574.aspx

Chính phủ. (2015a). Nghị định 99/2015/NĐ-CP ngày 20 tháng 10 năm 2015 của Chính phủ Quy định chi tiết thi hành một số điều của Luật nhà ở [Decree 99/2015/ND-CP dated 20 October 2015 of the Government detailing the implementation of a number of articles of the Housing Law]. Retrieved October 18, 2019, from https://thuvienphapluat.vn/van-ban/Bat-dongsan/Nghi-dinh-99-2015-ND-CP-huong-dan-Luat-Nha-o-294439.aspx

Chính phủ. (2015b). Nghị định 59/2015/NĐ-CP ngày 18 tháng 06 năm 2015 của Chính phủ về Quản lý dụ án đầu tu xây dụng [Decree 59/2015/ND-CP dated 18 June 2015 of the Government on construction project management]. Retrieved October 19, 2019, from https://thuvienphapluat.vn/van-ban/Xay-dung-Do-thi/Nghi-dinh-59-2015-ND-CP-quan-lydu-an-dau-tu-xay-dung-278744.aspx

Chính phủ. (2020). Nghị định số 25/2020/NĐ-CP ngày 28 tháng 02 năm 2020 của Chính phủ về Quy định chi tiết thi hành một số điều của Luật Đấu thầu về lựa chọn nhà đầu tu [Decree 25/2020/ND-CP dated 28 February 2020 of the Government etailing the implementation of a number of articles of the Bidding Law regarding investor selection]. Retrieved May 5, 2019, from https://thuvienphapluat.vn/van-ban/Dau-tu/Nghi-dinh-25-2020-ND-CP-huong-danLuat-Dau-thau-lua-chon-nha-dau-tu-347400.aspx

Quốc hội. (2013a). Luật đấu thầu số 43/2013/QH13 của Quốc hội nuớc Cộng hòa xã hội chủ nghĩa Việt Nam khóa XIII, kỳ họp thú 6 thông qua ngày 26 tháng 11 năm 2013 [Law on Bidding No. 43/2013/QH13 of the National Assembly of the Socialist Republic of Vietnam, term XIII, 6th session passed on November 26, 2013]. Retrieved May 6, 2019, from https://thuvienphapluat.vn/van-ban/Dau-tu/Luat-dau-thau-2013-215838.aspx 
Quốc hội. (2016). Luật đấu giá số 01/2016/QH14 của Quốc hội nước Cộng hòa xã hội chủ nghĩa Việt Nam khóa XIV, kỳ họp thú 2 thông qua ngày 17 tháng 11 năm 2016 [Law on Auction No. 01/2016/QH14 of the National Assembly of the Socialist Republic of Vietnam XIV, 2nd session passed on November 17, 2016]. Retrieved May 7, 2019, from https://thuvienphapluat.vn/vanban/Bo-may-hanh-chinh/Luat-dau-gia-tai-san-2016-280115.aspx

Quốc hội. (2013b). Luật đất đai số 45/2013/QH13 của Quốc hội nuớc Cộng hòa xã hội chủ nghĩa Việt Nam khóa XIII, kỳ họp thú 6 thông qua ngày 29 tháng 11 năm 2013 [Land Law No. 45/2013/QH13 of the XIII National Assembly of the Socialist Republic of Vietnam, the 6th session passed on November 29, 2013]. Retrieved May 8, 2019, from https://thuvienphapluat.vn/van-ban/Bat-dong-san/Luat-dat-dai-2013-215836.aspx

Quốc hội. (2014a). Luật Nhà ở số 65/2014/QH13 của Quốc hội nước Cộng hòa xã họi chủ nghĩa Việt Nam khóa XIII, kỳ họp thư 8 thông qua ngày 25 tháng 11 năm 2014 [Housing Law No. 65/2014/QH13 of the National Assembly of the Socialist Republic of Vietnam, term XIII, 8 session passed on November 25, 2014]. Retrieved May 9, 2019, from https://thuvienphapluat.vn/van-ban/Bat-dong-san/Luat-Nha-o-2014-259721.aspx

Quốc hội. (2006). Luật Kinh doanh bất động sản số 63/2006/QH11 của Quốc họi nuớc Cộng hoà xã hội chủ nghĩa Việt Nam khoá XI, kỳ họp thư 9 thông qua ngày 29 tháng 6 năm 2006 [Real Estate Business Law No. 63/2006/QH11 of the XIth National Assembly of the Socialist Republic of Vietnam, the 9th session passed on June 29, 2006]. Retrieved May 10, 2019, from https://thuvienphapluat.vn/van-ban/Thuong-mai/Luat-kinh-doanh-bat-dong-san-2006-632006-QH11-12982.aspx

Quốc hội. (2009). Luật Quy hoạch số 30/2009/QH12 của Quốc hội nước Cộng hoà xã hội chủ nghĩa Việt Nam khoá XII, kỳ hop thư 5 thông qua ngày 17 tháng 6 năm 2009 [Law on Planning No. 30/2009/QH12 of the XIIth National Assembly of the Socialist Republic of Vietnam, the 5th session passed on June 17, 2009]. Retrieved May 11, 2019, from https://thuvienphapluat.vn/van-ban/Xay-dung-Do-thi/Luat-quy-hoach-do-thi-2009-302009-QH12-90631.aspx

Quốc hội. (2014b). Luật xây dụng số 50/2014/QH13 của Quốc hội nước Cộng hòa xã hội chủ nghĩa Việt Nam khóa XIII, kỳ họp thư 7 thông qua ngày 18 tháng 6 năm 2014 [Law on Construction No. 50/2014/QH13 of the National Assembly of the Socialist Republic of Vietnam, term XIII, 7 session passed on June 18, 2014]. Retrieved May 12, 2019, from https://thuvienphapluat.vn/van-ban/Xay-dung-Do-thi/Luat-Xay-dung-2014-238644.aspx

Sở xây dựng TPHCM. (2020). Công văn 2363/SXD-PTĐT ngày 06/3/2020 của Sở xây dụng TPHCM về việc hoàn thiện quy trình thục hiện dụ án nhà ở thuơng mại theo quy định của Luật Đầu tu và Luật Nhà ở [Official dispatch 2363/SXD-PTDT dated 06 March 2020 of the Department of Construction of Ho Chi Minh City on completing the process of implementing commercial housing projects in accordance with the Law on Investment and the Housing Law]. Retrieved May 13, 2019, from https://thuvienphapluat.vn/cong-van/Dau-tu/Cong-van-2363-SXDPTDT-2020-du-an-nha-o-thuong-mai-theo-Luat-Dau-tu-So-Xay-dung-Ho-Chi-Minh440145.aspx

Văn phòng chính phủ. (2020). Công văn số 2789/VPCP-CN ngày 10 tháng 4 năm 2020 của Văn phòng Chính phủ thông báo ý kiến chỉ đạo của Phó thủ tướng Chính phủ Trịnh Đình Dũng về các vuóng mắc của TPHCM [Official dispatch 2789/VPCP-CN dated 10 April 2020 of the Government Office informs the direction of Deputy Prime Minister Trinh Dinh Dung on problems in Ho Chi Minh City]. 
Ủy ban nhân dân thành phố Hồ Chí Minh. (2020). Danh muc Nhà ở thưong mai có nguồn gốc đất do đền bù đất nông nghiệp hoặc sủ dụng đất chuyên dùng (Ban hành kèm theo Công văn 1225/UBND-ĐT ngày 04 tháng 4 năm 2020 của UBND thành phố Hồ Chí Minh) [List of commercial houses with land origin due to agricultural land compensation or special use land (Enclosed with Official Letter 1225/UBND-DT dated April 4, 2020 of Ho Chi Minh City People's Committee)].

Ủy ban nhân dân tỉnh Phú Yên. (2007). Quyết định số 2007/QĐ-UBND ngày 09 tháng 12 năm 2019 của UBND Tỉnh Phú Yên ban hành quy định về việc tổ chưc lựa chọn chủ đầu tu thực hiện dụ án dầu tu xây dụng nhà ở, sủ dụng vốn ngoài ngân sách theo Luật Nhà ở trên địa bàn Tỉnh Phú Yên [Decision 2007/QD-UBND dated 09 December 2019 of People's Committee of Phu Yen Province promulgating regulations on the selection of investors to implement housing investment projects, using off-budget capital according to Housing Law in Phu Yen Province]. $\quad$ Retrieved May 14, 2019, from http://soxaydung.phuyen.gov.vn/wps/portal/Home/page/thongbao/qd+ubnd+lua+chon+nha+dau+da+nha+o+ngoai+ngan+sach 